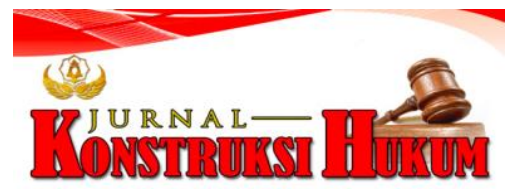

\title{
SANKSI HUKUM PENGHINAAN TERHADAP ORANG YANG SUDAH MENINGGAL MELALUI MEDIA SOSIAL DI INDONESIA
}

\author{
Kadek Suryasantosa, Anak Agung Sagung Laksmi Dewi, I Made Minggu Widyantara \\ Fakultas Hukum Universitas Warmadewa, Denpasar-Bali, Indonesia \\ suryasantoss@gmail.com, laksmidewi29@gmail.com, mademinggu21@gmail.com
}

\begin{abstract}
Abstrak
Saat ini, kemajuan terhadap teknologi informasi, globalisasi serta media elektronik semakin menyebar diberbagai bidang kehidupan masyarakat. Kemajuan tersebut dengan adanya sebuah jaringan internet sangat mudah mengoperasikannya melalui media yaitu media elektronik. Adanya jaringan internet membuat manusia mudah melakukan berbagai hal seperti pertukaran berbagai informasi yang bisa didapat dengan cukup mudah, serta biaya yang cukup murah. Oleh sebab itu manusia bisa berbuat tindakan hal-hal negatif yang tidak sepantasnya dilakukan demi kepentingan pribadi mereka. Penelitian ini bertujuan untuk menjelaskan pengaturan hukum penghinaan terhadap orang yang sudah meninggal dan menjelaskan sanksi pidana kepada tindak pidana penghinaan melalui media sosial terhadap orang yang sudah meninggal. Penelitian ini didesain menggunakan metode penelitian hukum normatif, dengan pendekatan masalah secara konseptual dan pendekatan kasus. Sumber data yang diguankan adalah sumber data hukum primer, sekunder dan tersier. Data dikumpulkan dengan cara rnencatat, rnengutip, membaca, maupun rneringkas literatur yang mengacu terhadap perubahan status jenis kelamin di Indonesia. Setelah data terkumpul, selanjutnya di analisis dengan sistematis dan mengaitkannya dengan bahan hukum. Hasil penelitian ini menunjukkan bahwa Pasal 320 serta 321 KUHP akan dipakai sebagai dasar hukum dari suatu jenis tindak penghinaan dan Pasal 27 ayat 3 UU ITE akan dipakai dengan tujuan dasar tentang suatu media yang telah digunakan. Selanjutnya Kasus penghinaan pada orang meninggal dapat dikenakan sanksi penjara selama enam (6) bulan seperti itu isi dari pasal 446 ayat I Rancangan Undang-Undang KUHP tetapi kasus ini tidak bisa berjalan proses hukumnya apabila tidak ada pelaporan pihak keluarga yang bersangkutan.
\end{abstract}

Kata Kunci: Media sosial, Penghinaan, Sanksi Hukum

\begin{abstract}
Currently, advances in information technology, globalization and electronic media are increasingly spreading in various fields of public life. This progress with the existence of an internet network is very easy to operate through the media, namely electronic media. The existence of it makes it easy for humans to do various things such as exchanging various information that can be obtained quite easily, and low cost. Therefore, people can do negative things that are not supposed to be done for their personal interests. This study aims to explain the legal arrangements for insulting people who have died and to explain criminal sanctions for criminal acts of humiliation through social media for those who have died. This research was designed using normative legal research methods, with a conceptual problem approach and a case approach. The data sources used are primary, secondary and tertiary legal data sources. Data were collected by recording, quoting, reading, and summarizing the literature referring to changes in gender status in Indonesia. After the data is collected, it is then analyzed systematically and relates it to legal materials. The result of this study indicates that Articles 320 and 321 of the Criminal Code will be used as the legal basis for a type of insulting act and Article 27 paragraph 3 of the ITE Law will be used for the basic purpose of a media that has been used. Furthermore, cases of insulting a deceased person can be subject to imprisonment for six (6) months as is the content of Article 446 paragraph I of the Draft Criminal Code but the legal process cannot proceed if there is no reporting from the family concerned.
\end{abstract}

Keywords: social media, humiliation, sanctions, technology

\section{PENDAHULUAN}

Teknologi semakin hari semakin berkembang ada kemajuan dalamn mendapatkan akses dengan sangat mudah dalaam menggunakan media elektronik. Adanya kemajuan ini merupakan hal yang sangat luar biasa dikarenakan dapat mendapatkan segalanya dengan mudah dan praktis. Sehingga mempercepat kinerja dari seseorang, namun perkembangan teknologi ini bukan saja membawa 
kemanfaatan yang beruntung, namu tindak kejahatan yang semakin berkembang kecanggihannya seperti menjalankan penipuan melalui jual beli dan masih banyak lagi, salah satunya penghinaan melalui media sosial (Sumenge, 2013).

Belakangan ini sangat marak tersebar tuduhan dengan penghinaan dan atau pencemaran berupa nama atau identitas yang baik pada seseorang yang sudah tiada dan ada didunia. Penyebabnyapun sangat beragam mulai dari menulis di mailing list, melaporkan tentang korupsi, meneruskan forward email, memberitakan peristiwa di media sosial dan sebagainya (Andi, 1985). Dewasa ini, yaitu disaat masyarakat sudah bisa menggunakan media sosial yang sudah berkembang ini tentunya harus memiliki yang namanya suatu kesiapan mental dalam menggunakan media sosial jika tidak sesuai maka terjadi penyimpangan seperti kejahatan di media ini. Setiap manusia memiliki keunikan yang dimana ada unsur rasa, cipta, karsa yang dimiliki oleh setiap orang artinya anugerah yang diberikan oleh Tuhan. Dengan unsur-unsur tersebutlah manusia mampu mengertikan dan merasakan berbagai pengalaman baik dan buruk yang berbentuk fisik maupun non fisik, abstrak maupun konkret dan subjektif maupun objektif.

Anugerah yang diberikan tersebut mampu membuat manusia memiliki kemampuan untuk melakukan sebuah interaksi sosial antar individu, kelompok, hingga yang paling luas pada masyarakat (Willya, 2018). Pada situasi saat ini kejadian seperti itu dapat dimasukan kedalam tindak pidana penghinaan atau bisa jelaskan pada ujaran kebencian. Sesuai surat edaran yang dijabarkan oleh kapolri menjelaskan dengan sangat jelas pada dasarnya bahwasannya ujaran kebencian ini adalah kejadian perbuatan dimana merupakan suatu tindak pidana dan sudah ada dimuat dalam KUHP atau diatur didalamnya seperti penistaan dan lain lain (Rahmawati et al., 2017).

Ada beberapa penelitian terdahulu yang relevan dengan penelitian ini yaitu (Ahnaf \& Suhadi., 2014); (Permatasari \& Wijaya, 2019); (David, 2020) mengungkapkan bahwa penyelesaian masalah ujaran kebencian di sosial media diatur pada pasal 27, 28 dan 29 pada Undang-undang ITE memang tidak pernah berhenti, selanjutnya praktik ujaran kebencian merupakan suatu pidana kejahatan, oleh karena itu hukum telah mengatur tentang perbuatan tersebut, baik itu yang telah tertuang dalam KUHP, UU No 11 Tahun 2008 tentang Informasi dan Transaksi Elektronik dan UU No. 40 Tahun 2008 tentang penghapusan diskriminasi ras dan etnis. Kebencian di sosial media muncul karena faktor ekonomi. Walaupun sudah banyak penelitian tentang pencegahan masalah lewat sosial media bahkan diatur dalam beberapa pasal undang-undang serta dirumuskan satu undang-undang ITE, namun sampai saat ini kasus ujaran kebencian di sosial media semakin marak dan tidak bisa dibatasi, oleh sebab itu penelitian ini mencoba menjelaskan pengaturan hukum penghinaan terhadap orang yang sudah meninggal dan menjelaskan sanksi pidana kepada tindak pidana penghinaan melalui media sosial terhadap orang yang sudah meninggal.

\section{METODE PENELITIAN}

Penelitian ini menggunakan penelitian hukum norrnatif, yaitu mengacu kepada studi kepustakaan di bidang hukum, dengan rnenggunakan pendekatan masalah secara konseptual dan pendekatan kasus (Waluyo, 2002). Adapun sumber data yang digunakan yaitu bahan hukum primer berpedoman dengna undang-undang dan keputusan yang mengikat, sedangkan bahan hukum sekunder diperoleh melalui jurnal, buku hukum, serta internet yang memuat mengenai penghinaan di media sosial terhadap seorang individu yang sudah meninggal dunia, selanjutnya bahan hukum tersier didapatkan melalui kamus hukum serta ensiklopedia yang berkaitan mengenai informasi hukum. Data dikumpulkan dengan cara mencatat, mengutip, membaca, maupun meringkas literatur yang mengacu terhadap masalah yang sedang diteliti. Setelah data selesai dikumpulkan, maka dianalisis dengan sistematis dan mengaitkannya dengan masalah yang sedang diteliti (Hadjon, 1993).

\section{HASIL DAN PEMBAHASAN}

\section{Pengaturan Hukum Penghinaan terhadap Orang yang Sudah Meninggal Melalui Media Sosial}

Penghinaan orang yang sudah meninggal lewat sosial media yakni sesuatu perbuatan atau perilaku sikap melanggar nama baik serta perilaku menyimpang terhadap norma rnasyarakat seperti dalam mengamati atau mengomentari kepentingan diri seseorang pada saat di dalam pergaulan yang biasa dilakukan. Penghinaan merupakan perilaku yang menimbulkan suatu penyerangan kehormatan terhadap diri orang lain yang tentunya menimbulkan perasaan seperti rasa tidak percaya diri dan merasa harga diri menjadi rendah terhadap seseorang yang terserang tersebut. 
Perlakuan penghinaan tersebut tentunya tidak bisa kita hindari akan tetapi jika itu terjadi maka pastinya kita akan bereaksi atau meresponnya dan tentunya akan menimbulkan konflik dan juga tergantung bagaimana setiap orang bereaksi tentang penghinaan yang dilakukan oleh orang lain tersebut. Seseorang pada dasarnya mempunyai dua sisi subjektif dan objektif yaitu sisi subjektif adalah suatu pengakuan dari orang itu sendiri bahwa perasaan serta kehormatannya sudah dihina atau direndahkan oleh orang lain dan sisi objektif adalah perilaku yang dirasakan pada sebuah penghinaan ini dapat dinilai dengan nalar yang sehat serta hal ini adalah tidak berupa perasaan (Satrio, 2005). Yang dijelaskan pada delik aduan (kfacht defict) adalah sebagai pembatasan inisiatif jaksa melakukan penuntutan. Tersedia atau tidak adanya aturan kepada delik ini mengikuti persetujuan dari yang dirugikan atau korban (orang) sebagaimana ditentukan pada undang-undang. Delik tersebut membahas kepentingan korban (Sudarto, 1990)

Penghinaan tidak termasuk dalam sifat pencemaran ini yakni setiap penghinaan pada pengertiannya yang bersifat sosiologis. Maka atas dasar itu penghinaan secara umum dijelaskan sebagai usaha menjelekkan orang, jadi penghinaan ringan tersebut bisa dimaknai dengan setiap upaya menjelekkan orang lain yang tidak bersifat pencemaran. Agar terbentuknya suatu penghinaan ringan, selain hanya dapat terjadi atau dapat dilakukan di tempat umum baik dengan lisan maupun tulisan, penghinaanya tersebut juga dapat dilakukan saat di muka atau di hadapan korban atau orangnya secara langsung berupa perkataan atau tindakan. Perbuatan dari orang yang melakukan Tindakan dengan memarahi seorang memakai dengan kalimat kata tidak enak di dengar atau dengan perbuatannya seperti mengeluarkan ludah untuk orang lain, merupakan tindakan perbuatan bisa dikategorikan dengan penghinaan ringan. Pada unsur sengaja merujuk dengan adanya kesengajaan dalam memberikan pengaduan dengan pemberitahuan palsu dengan penguasa mengenai seseorang menyebabkan kehormatan atau nama baiknya seseorang terserang, serta hal itu wajib dibuktikan. Jika seseorang memberitahu atau membuat pengaduan palsu dan diberikan kepada penguasa akan tetapi pengaduan iru keliru dan tidak benar serta perbuatan ini dilakukan dengan tanpa kesengajaan. Jika hal ini terjadi maka orang tersebut bisa dikatakan sudah melakukan tindak pidana dalam Pasal 317 KUHP.

Kehormatan tentunya dimiliki masing-masing keluarga, individu serta ahli waris seseorang pada orang yang telah meninggal. Pastinya kehormatan tersebut harus dijaga dan merniliki hak untuk melindungi kehormatan yang dimiliki dari masing-masing seseorang. Jika sebelumnya hal ini sudah dijabarkan bahwasannya objek delik pencemaran nama baik yaitu harga diri maka seseorang yang masih hiduplah mempunyai harga diri. Perbuatan penghinaan kepada orang yang sudah meninggal pada intinya diajukan kepada kehormatan atas nama baik terhadap keluarga. Hal ini juga merupakan Kepentingan hukum yang hendak dilindungi pada Pasal 320 KUHP.

\section{Sanksi Pidana Kepada Tindak Pidana Penghlnaan terhadap Orang yang Sudah Meninggal Melalui Media Sosial}

Orang yang sudah meninggal tentunya tetap memiliki nama baik yang harus dijaga dan diperhatikan oleh keluarganya agar terhindar dari sebuah penghinaan. Permasalahan seperti ini tentunya bisa dilakukan oleh seseorang yang ingin mencoreng nama baik untuk keinginan atau kepuasaannya pribadi agar terpenuhi dan tidak memikirkan dampaknya. Ketika permasalahan seperti ini muncul pastinya dapat menimbulkan tanggapan. Seperti timbulnya sesuatu bentuk keinginan melindungi atau memberikan hal perlindungan menunjukkan bukti kepentingan dari seorang ahli waris untuk menjaga kehormatan keluarganya yang sudah tiada, pastinya hal ini diatur dalam KUHP di dalam pengaturan tersebut memberikan jabaran bahwa ketika seseorang yang telah tiada dihina maka hal tersebut merupakan tindak pidana aduan (Prodjodikoro, 1989).

Pada dasarnya hal perbuatan tersebut bisa disebut sebuah pidana penistaan seperti diatur dalam pengaturannya dalam Pasal 310 KUHP menerangkan bahwa perbuatan baik dilakukan sengaja merniliki unsur yang subjektif sudah ada pada pelaku tindak pidana. Tindakan kesengajaan ini adalah tindakan perbuatan tentunya dengan disadari lebih tepatnya dilakukan dengan dirinya sendiri dengan kesadaran yang penuh. Sadar yang dimaksud adalah bahwa seseorang tersebut atau pelaku paham akan yang mereka lakukan itu salah tentunya melanggar kehormatan atau melecehkan nama baik dari korban yang dilakukan.

Perbuatan menghina adalah termasuk penyerangan kehormatan hal ini memang bukan tindak pelanggaran penyerangan melalui fisik oleh seseorang akan tetapi menyerang secara perasaan kepada 
kehormatan tersebut sehingga hal ini pastinya menyebabkan tercemarnya kehormatan tersebut. Seorang pelaku biasanya melakukan dengan memfitnah akan sesuatu hal yang tidak berkaitan dengan korban yang pastinya membuat tercemar atau kehormatannya itu jatuh. Berikut cara yang bisa dilakukan untuk melakukan tindakan tersebut adalah terdapat 2 (dua) cara yang pertama yaitu difitnahkan mengenai hal yang sifatnya sudah jelas pasti, seperti tempat dan waktu. Tujuan melakukan penuduhan ini adalah untuk menyebarkan informasi yang merugikan orang yang terserang tentunya sangat merugikan pihak yang terserang tersebut. Maka dapat dipastikan penuduhan ini adalah untuk mencoreng nama baik agar tidak menjadi terhormat di masyarakat atau pada muka umum melalui informasi.

Penjelasan pada muka umum bisa dijelaskan dalam artian sempit yakni dilihat dengan orang saat hadir di tempat publik tersebut saat tindak pidana itu terjadi dan jika di artikan dengan luas yaitu bahwa bisa juga dapat mendengar melalui radio dan tv. Pada dasarnya menghina bisa dijelaskan dengan menyerang sebuah identitas nama seseorang. Pada intinya penghinaan memakai wadah teknologi informasi agar dapat diaksesnya atau menyebarkan informasi mengenai penghinaan kepada seseorang adalah sebuah pelanggaran hukum sebagaimana yang sudah diatur dalam UU ITE berisikan tentang sebagaimana mendistribusikan bisa dijelaskan bahwa hal ini merupakan perbuatan yang sifatnya menyebarkan info kepada seseorang ataupun ternpat adalah sesuatu perbuatan hukum yang dikerjakan melalui pemanfaatan teknologi informasi pada media elektronik. Tindakan "Agar bisa diaksesnya" mengenai informasi mempunyai sifat yang abstrak dari tindakan perlu diketahui prosedur ketika ingin melindungi atau menjaga sebuah kehormatan salah satunya dengan melakukan aduan diwakilkan oleh ikatan keluarga seperti saudara ataupun hasil darah perkawinan tersebut bisa melakukan sebuah tindakan pengaduan yang tentunya hanya bisa dilakukan oleh orang yang sudah disebutkan diatas. Melakukan penghinaan orang meninggal bisa dikenai sanksi penjara selama enam (6) bulan sesuai pasal 446 ayat 1 Rancangan Undang-Undang KUHP, namun hal ini tidak bisa berjalan proses hukum ini apabila tidak ada yang melapor dari pihak keluarga. Jika hal ini terus dibiarkan dan tidak adanya aduan maka proses hukum pastinya tidak akan berjalan sehingga menyebabkan semakin banyaknya pelaku kejahatan yang menyebarkan informasi menyerang sebuah harga diri atau kehorrnatan melalui media sosial akan terus berlanjut dan tidak akan timbul rasa jera dalam diri mereka yang pastinya akan terus berkembang ketika hal ini dibiarkan dengan tidak adanya laporan sama sekali dari pihak yang mengadukan untuk melakukan proses hukum.

\section{SIMPULAN DAN SARAN}

\section{Simpulan}

Dari hasil nanlisis data dapat disimpulkan bahwa pengaturan hukum penghinaan kepada seseorang yang telah tiada mempunyai sebuah dasar hukum yaitu Pasal 320 serta Pasal 321 akan tetapi pada kasus penghinaan yang menggunakan alat media sebagai dikenai Pasal 27 Ayat 3 yang dimana dipakai dalam suatu dasar yang terkait hukum dan merupakan macam-macam media yang dipakai untuk melakukan hal tersebut. Patut dipahami syarat keinginan untuk melindungi suatu kehormatan adalah sarunya yakni dengan aduan tentunya dapat dilaksanakan pada yang mempunyai atau memiliki ikatan keluarga contohnya yang sedarah maupun hasil darah perkawinan itu dapat mengambil sebuah tindakan pengaduan pastinya hanya dapat dilaksanakan dengan orang yang dijelaskan diatas tadi, selanjutnay sanksi pidana kepada pelaku penghinaan di sosial media kepada seseorang yang sudah tiada adalah perbuatan yang merupakan penyerangan kehormatan kasus ini bukan tindak pelanggaran penyerangan seperti fisik pada seseorang akan tetapi hal menyerang perasaan kepada kehormatan tersebut menyebabkan kasus ini pastinya membuat tercemarnya kehormatan ini. Kasus penghinaan pada orang meninggal dapat dikenakan sanksi penjara selama enam (6) bulan sesuai pasal 446 ayat 1 Rancangan Undang-Undang KUHP tetapi kasus ini tidak bisa berjalan proses hukumnya apabila tidak ada pelaporan pihak keluarga yang bersangkutan.

\section{Saran}

Dari hasil penelitian di atas, adapun yang menjadi saran yaitu sebaiknya pemerintah dalam menyikapi kasus penghinaan yang semakin berkembang melalui media sosial yang tentunya banyak rnerugikan orang yang mendapatkan penyerangan secara non fisik ini. Walaupun penghinaan ini dilakukan pada orang yang sudah meninggal dunia akan tetapi orang tersebut pastinya memiliki keluarga yang tetap menjaga sebuah kehormatan serta harga diri yang ada di dalam keluarga itu. Maka dari itu alangkah 
baiknya pemerintah cepat untuk menyelesaikan rancangan undang-undang KUHP yang sudah dibuatnya ini, selanjutnya diharapkan kepada masyartkat untuk tetaplah menggunakan media sosial dengan tidak menjatuhkan seseorang dengan sebuah penghinaan atau pelecehan nama baik, apalagi menjelekan orang yang sudah meninggal dunia tentunya bisa menyebabkan reaksi dari keluarga yang ditinggalkan karena merasa terlecehkan dan menjatuhkan martabat. Hal ini juga menyimpaang pelanggaran norma di masyarakat. Kasus seperti ini tidak bisa dibiarkan maka dari itu sebaiknyat masyarakat jangan sampai menggunakan media elektronik dengan tidak benar dan perlu dipahami penyerangan bukan hanya dilakukan secara fisik tetapi dapat berbentuk secara non fisik seperti perkataan yang tidak pantas didapatkan di muka umum maupun di media sosial yang digunakan.

\section{DAFTAR PUSTAKA}

Ahnaf, M. I., \& Suhadi. (2014). Isu-isu Kunci Ujaran Kebencian (Hate Speech): Implikasinya terhadap Gerakan Sosial Membangun Toleransi. Jurnal Multikultural \& Multireligius, 13(3), $15-25$.

Andi, H. (1985). Delik Penyelundupan Cetakan Kedua (CV. Akadem). Jakarta.

David. (2020). Faktor Penyebab Pelaku Melakukan Ujaran Kebencian (Hate Speech) dalam Media Sosial Tinjauan Kriminologis. 3(3).

Hadjon, P. M. (1993). Penghantar Hukum Administrasi. University Press.

Permatasari, I. A., \& Wijaya, J. H. (2019). Implementasi Undang-Undang Informasi dan Transaksi Elektronik dalam Penyelesaian Masalah Ujaran Kebencian pada Media Sosial.

Prodjodikoro, W. (1989). Arns- Asas Hukum Pidana. Lombok: PT. Erecos.

Rahmawati, Novi, Syarin, Alvin, Mulyadi, \& Mahmud. (2017). Rahmawati Harefa, Novi 2017, Implikasi Perubahan Undang-Undang Informasi dan Transaksi Elektronik Terhadap Tindak Pidana Ujaran Kebencian (Hate Speech Jurnal Hukum. Jurnal Mahupiki, 1(1).

Satrio. (2005). Gugat Perdata Atas Dasar Penghinaan sebagai Tindakan Melawan Hukum. Jakarta: Cita Aditya Bakti.

Sudarto. (1990). Hukum Pidana Islam. Semarang: Yayasan Sudarto.

Sumenge, M. M. (2013). Penipuan Menggunakan Media Internet Berupa Jualbeli Online. Jurnal Lex Crimen, 2(4), 102-112.

Waluyo, B. (2002). Penelitian Hukum Praktek. Sinar Grafika.

Willya, E. (2018). Senarai Penelitian Islam Kontemporer Tinjauan Multikultural. Yogyakarta: Deepublish. 